\title{
Correction to "Long QT2 Mutation on the Kv11.1 Ion Channel Inhibits Current Activity by Ablating a Protein Kinase $\mathrm{C} \alpha$ Consensus Site"
}

\begin{abstract}
In the above article [Donovan AJ, Lansu K, Williams JG, Denning MF, and Gentile S (2012) Mol Pharmacol, 82(3): 428-437; DOI: https://doi.org/10.1124/mol.112.077966], the following funding information was omitted:
\end{abstract}

This research was supported in part by the Intramural Research Program of the National Institutes of Health National Institute of Environmental Health.

The authors regret this error and any inconvenience it may have caused. 